\title{
Prospects of Using Platelets as Peripheral Marker to Study the Role of GABA in Autism
}

\author{
Saima Khan', Kaneez Fatima-Shad ${ }^{2}$, Hashmet Parveen Ghouse ${ }^{1}$ \\ ${ }^{1}$ Department of Biomedical Sciences, PAP RSB Institute of Health Sciences, University Brunei, Darussalam, \\ Brunei Darussalam \\ ${ }^{2}$ School of Medical and Molecular Biosciences, Faculty of Science, University of Technology, Sydney, Australia \\ Email: ftmshad@gmail.com
}

Received 17 September 2014; revised 17 October 2014; accepted 25 October 2014

Copyright (C) 2014 by authors and Scientific Research Publishing Inc.

This work is licensed under the Creative Commons Attribution International License (CC BY). http://creativecommons.org/licenses/by/4.0/

(c) (i) Open Access

\begin{abstract}
Literature indicated that platelets could be used as a model for neuronal receptors such as $\gamma$ amino butyric acid (GABA) and serotonin. Research work exhibited the presence of low levels of GABA and high levels of serotonin concentration in the platelets of autistic children as compare to their healthy counter parts. There are also other evidences pointing out to the significant role of GABA in autism such as association of g-band frequency with the cortical concentration of GABA and gabapentin (GABA analogue) specifically inhibits the cytosolic branched chain amino transferase (BCATc); an enzyme responsible to modulate glutamate availability for the synthesis of GABA.
\end{abstract}

Keywords

Autism, GABA, Serotonin, Platelets, Neurotransmitters

\section{Introduction}

It was previously suggested that platelets could be used as a model for neuronal receptors such as amino butyric acid (GABA) and serotonin [1] [2]. Our work in progress and literature [3], revealed the presence of low levels of GABA and high levels of serotonin concentration in the platelets of autistic children as compare to their age matched healthy counter parts. There are also other evidences pointing out to the significant role of GABA in autism such as association of g-band frequency with the cortical concentration of GABA [4] and gabapentin (GABA analogue) specifically inhibit cytosolic branched chain amino transferase (BCATc); an enzyme responsible to modulate glutamate availability for the synthesis of GABA [5].

\section{GABA and Other Neurotransmitters}

There are many neurochemicals such as GABA, Glutamate, serotonin, dopamine, and acetylcholine present be- 
fore the neuronal differentiation does occur in the fetal brain and play modulatory role in neuronal differentiation, proliferation and migration (Table 1). The developmental abnormalities in autism may be related to the expression of numerous genes that normally silenced during the post natal development [6]. Many genes remain switched on which stunned axodendrtic development but still GABA seems to be the most distinguished candidate for autism. At the early stage of development neuronal GABA receptors function as excitatory due to the high $\mathrm{Cl}^{-}$concentration inside the cell, and resultant efflux of $\mathrm{Cl}^{-}$. Dysregulation of monoamines neurotransmitters such as serotonin can modify neural activity widely across the forebrain, and thereby affect the progressive refinement and emergent efficiencies of all forebrain-processing systems. GABA and its relationship with other neurotransmitters and neuromodulators may involve in triggering autism and autistic behaviors. GABA related changes in neurotransmitters, branched chain amino acids, cell adhesion molecules and neurotropic factors effect on the developing fetus and newborn.

\section{Neurotransmitters Interaction with GABA and Development of Autism}

During the early stage of development GABAergic excitation cooperates with N-methyl-D-aspartate receptors (NMDARs) to drive spontaneous synchronous activity (SSA) by removal of $\mathrm{Mg}^{+}$blockade of NMDA and influx of $\mathrm{Ca}^{++}$[7]. SSA is fundamentally important for developing neuronal network and suppressed GABAergic inhibition involves in pathophysiology of autism through this pathway. Similarly, reduced availability of glutamic acid decarboxylase (GAD), enzyme responsible for the synthesis of GABA can lead to delayed myelination and synaptic maturation, learning and memory processes. While decrease numbers of GABA interneuron per units of cortical minicolumns and low levels of GABA concentration at the synapse shown to be involved in autism. GABAergic neurons are sensitive to glutamate analog (NMDA) resulting in the loss of inhibitory control which in turn damage the large pyramidal and multipolar neurons and may contribute to the pathology of autism [8]. Significant loss of Purkinje cells and pyramidal neurons in the frontal cortex, and in limbic system were observed in autism. GABAergic dysfunction may either result in direct alterations in GABA systems or in neuromodulation of GABAergic neurons via several neuromodulators that are reported to be involved in such changes, potentially with synergistic effects (Table 2). Acetylcholine is one of them cholinergic dysfunction may have an indirect contribution in the development of autistic symptoms via its influence on GABAergic neurons, a correlate of prior GABAergic dysfunction, or work as a direct contributor through its influence on synaptic development [9]. The $\alpha 7$ nicotinic acetylcholine receptor which has been reported to be found on the surface of GABA inhibitory neurons promote, GABA release and can restore diminished inhibitory tone. While $\alpha 4 \beta 2$ nicotinic acetylcholine receptor which has regulatory effect on GABAergic neurons have shown to be decreased in the

Table 1. Modulatory action of Serotonin receptors on GABAergic receptors neurotransmission in various brain regions.

\begin{tabular}{|c|c|c|c|c|}
\hline \multicolumn{5}{|c|}{ Table Serotonin modulatory effect on GABA } \\
\hline Serotonin/receptors & $\begin{array}{l}\mathrm{GABA} / \\
\text { receptors }\end{array}$ & Mechanism involved & Location in brain regions & References \\
\hline $5 \mathrm{HT}$ & $\mathrm{GABA}_{\mathrm{B}}$ & $\begin{array}{l}\text { 5-HT inhibitsGABA } A_{B} \text { mediated IPSCs acting } \\
\text { both pre and post synaptically }\end{array}$ & CA3 pyramidal neurons & [17] \\
\hline $5 \mathrm{HT}$ & $\mathrm{GABA}_{\mathrm{B}}$ & $\begin{array}{l}\text { 5-HT and } \mathrm{GABA}_{\mathrm{B}} \text { receptors increase and } \\
\text { decrease Ttype } \mathrm{Ca}^{2+}\end{array}$ & $\begin{array}{l}\text { Interneurons from stratum } \\
\text { lacunosum-moleculare }\end{array}$ & [18] \\
\hline $5-\mathrm{HT}_{3}$ & GABA & Stimulates GABA release & $\begin{array}{l}\text { Basolateral amygdala } \\
\text { (from interneurons) }\end{array}$ & [19] [20] \\
\hline $5-\mathrm{HT}_{2}$ and $5-\mathrm{HT}_{4}$ & $\mathrm{GABA}_{\mathrm{A}}$ & $\begin{array}{l}\text { Modulate post synaptically } \mathrm{GABA}_{\mathrm{A}} \\
\text { mediated effect }\end{array}$ & $\begin{array}{l}\text { Pyramidal neurons from } \\
\text { prefrontal cortex }\end{array}$ & {$[21]$} \\
\hline $5-\mathrm{HT}_{2}$ & $\mathrm{GABA}_{\mathrm{A}}$ & $\begin{array}{l}\text { Promotes Phosphorylation of } \mathrm{GABA}_{\mathrm{A}} \text { receptors by } \\
\text { activating on protein kinase } \mathrm{C}(\mathrm{PKC}) \text { which reduces } \\
\mathrm{GABA}_{\mathrm{A}} \text { mediated } \mathrm{Cl}^{-} \text {currents. }\end{array}$ & $\begin{array}{l}\text { Pyramidal neurons from } \\
\text { prefrontal cortex }\end{array}$ & {$[21]$} \\
\hline $5-\mathrm{HT}_{4}$ & $\mathrm{GABA}_{\mathrm{A}}$ & $\begin{array}{c}\text { Modulates } \mathrm{GABA}_{\mathrm{A}} \text { mediated current depending on } \\
\text { protein kinase A (PKA)activation level }\end{array}$ & $\begin{array}{l}\text { Pyramidal neurons from } \\
\text { prefrontal cortex }\end{array}$ & {$[21]$} \\
\hline $5 \mathrm{HT}$ & GABA & $\begin{array}{l}\text { †GABA release, strengthen local GABAergic inhibition } \\
\text { and modulate thalamic processing of sensory signals }\end{array}$ & $\begin{array}{l}\text { Dendrites of thalamic } \\
\text { interneurons }\end{array}$ & {$[22]$} \\
\hline $5-\mathrm{HT}_{2}$ & $\mathrm{GABA}_{\mathrm{A}}$ & $\begin{array}{l}\text { Enhances } \mathrm{GABA}_{\mathrm{A}} \text { induced } \mathrm{Cl}^{-} \text {current acting } \\
\text { through a protein kinase dependent pathway }\end{array}$ & Spinal dorsal horn, & {$[23]-[25]$} \\
\hline
\end{tabular}


Table 2. Represent the role of neurotransmitters in the development of Autism and other Neurological disorders.

\begin{tabular}{|c|c|c|c|}
\hline \multicolumn{4}{|c|}{ Pathological maturation of neurotransmitter systems in the developmental of Autism } \\
\hline $\begin{array}{c}\text { Brain regions/ } \\
\text { migration } \leftrightarrow\end{array}$ & Synaptic integration $\leftrightarrow$ & Network activity/plasticity $\leftrightarrow$ & $\begin{array}{l}\text { Behavioral clinical } \\
\text { phenotype }\end{array}$ \\
\hline $\begin{array}{l}\text { Glutamate } \\
\text { Cortical region }\end{array}$ & $\begin{array}{c}\text { Blockade of } \\
\text { GABAergic activities }\end{array}$ & $\uparrow$ Cortical excitatory inputs & Autism \\
\hline Cortical region & $\begin{array}{l}\uparrow\left(5 \mathrm{HT} 2_{\mathrm{A}}\right) \text { receptor activity } \\
\text { on GABAergic interneurons }\end{array}$ & $\downarrow$ Glutamate signaling & $\begin{array}{l}\text { Developmental disorder } \\
\text { such as Autism }\end{array}$ \\
\hline $\begin{array}{l}\text { Pyramidal and } \\
\text { multipolar neurons }\end{array}$ & $\begin{array}{l}\text { GABAergic neurons are sensitive } \\
\text { to glutamate analog (NMDA) }\end{array}$ & $\begin{array}{l}\text { Damage the large pyramidal } \\
\text { and multipolar neurons }\end{array}$ & Autism \\
\hline $\begin{array}{l}\text { GABA } \\
\text { Cortex }\end{array}$ & $\begin{array}{l}\text { Postnatal } \downarrow \text { in cortical } \\
\text { GABAergic neurons }\end{array}$ & $\uparrow$ Excitation and $\uparrow$ Noise in Cortex & Autism \\
\hline $\begin{array}{l}\text { Acetylcholine } \\
\text { Cerebral neocortex }\end{array}$ & $\begin{array}{l}\downarrow \alpha 4 \beta 2 \text { nicotinic acetylcholine } \\
\text { receptor on GABAergic neurons }\end{array}$ & $\downarrow$ GABAergic activity & Autism \\
\hline Cerebellum & $\begin{array}{l}\downarrow \alpha 4, \alpha 2 \text { nicotinic } \\
\text { acetylcholine receptor }\end{array}$ & $\downarrow$ GABAergic activity & $\begin{array}{l}\text { Reported in } \\
\text { autistic patients }\end{array}$ \\
\hline Hippocampus & Prenatal stress & $\uparrow$ Level of acetylcholine & $\begin{array}{l}\text { Developmental disorders } \\
\text { including Autism }\end{array}$ \\
\hline Cerebral cortex & $\downarrow \alpha 4 \beta 2$ acetylcholine receptor & $\begin{array}{l}\downarrow \text { Interneuron GABAergic } \\
\text { neurotransmission }\end{array}$ & Autism \\
\hline $\begin{array}{l}\text { Serotonin } \\
\text { Cortex }\end{array}$ & $\begin{array}{l}\text { Destruction of 5HT afferents by } \\
\text { using Pchlorophenylalanine at } \\
\text { a critical period(E12 to E17) }\end{array}$ & $\begin{array}{l}\text { Abnormal distribution of } \\
\text { GABAergic interneurons }\end{array}$ & Developmental disorders \\
\hline Prefrontal cortex & $5 \mathrm{HT} 2_{\mathrm{A}}$ receptor agonists & $\begin{array}{c}\text { Reduced GABA }{ }_{\mathrm{A}} \text { currents by } \\
\text { activation of protein kinase (PKC) } \\
\text { which decreases GABA } \\
\mathrm{Cl}^{-} \text {currents }\end{array}$ & Autism \\
\hline $\begin{array}{l}\text { Prefrontal cortex } \\
\text { pyramidal neurons }\end{array}$ & $5 \mathrm{HT}_{4}$ receptor & $\begin{array}{l} \pm \mathrm{GABA}_{\mathrm{A}} \text { mediated current depending } \\
\text { on Protein Kinase (PKA) levels }\end{array}$ & Autistic Spectrum Disorder \\
\hline $\begin{array}{l}\text { Dopamine } \\
\text { cerebral cortex }\end{array}$ & $\begin{array}{l}\text { Pysiological changes in } \\
\text { dopamine D1 and D2 receptors }\end{array}$ & $\begin{array}{l}\text { Cause alteration } \\
\text { in GABA neuron migration } \\
\text { at the embryonic stage }\end{array}$ & Autism \\
\hline $\begin{array}{l}\text { Telencephalic } \\
\text { regions }\end{array}$ & DAergic innervation & significant GABA dysfunction & $\begin{array}{c}\text { Neuronal disorders including } \\
\text { schizophrenia }\end{array}$ \\
\hline
\end{tabular}

cerebral neocortex and in the cerebellum of autistic patients. The serotonergic system is involved in the regulation of emotional processes and cognitive behaviors. There are several 5HT receptors; most of them belongs to $\mathrm{G}$ protein family, while 5- $\mathrm{HT}_{3}$ receptor is a ligand-gated ion channel receptor and expressed on GABAergic neurons in neocortex and suggested to be involved in controlling excitation and inhibition of cortical columns. Activation of $5 \mathrm{HT}_{3}$ induces a transient enhancement of inhibitory postsynaptic currents (IPSCs) in neocortex and hippocampus [10]. 5- $\mathrm{HT}_{2 \mathrm{~A}}$ receptor agonists can reduce GABAA currents by activating protein kinase C (PKC) in most of prefrontal cortex pyramidal neurons and reduce GABAA mediated $\mathrm{Cl}^{-}$currents. The overlapping between expression of $5 \mathrm{HT}_{2 \mathrm{~A}}$ and $\mathrm{GABA}_{\mathrm{A}}$ receptors suggested that they may be co localized at some synapses of pyramidal neurons in the prefrontal cortex (Figure 1, [28]).

Similarly, $5 \mathrm{HT}_{4} \mathrm{R}$ are also located on pyramidal neurons of prefrontal cortex and has dual effect on $\mathrm{GABA}_{\mathrm{A}}$ mediated currents, i.e. can either enhance or depress depending on protein kinase A (PKA) levels. Dopamine (DA), a catecholamine synthesized from tyrosine by tyrosine hydroxylase is present in mesolimbic, nigrostrial, and mesocortical systems and are involved in controlling variety of functions such as cognition, motor function and reward mechanism. Ventral tegmental area (VTA) a group of neurons that are found on the floor of midbrain can mediate activation of mesofrontal DA system which effect on various neurotransmitters including $5 \mathrm{HT}$, NE, acetylcholine, GABA and opioid peptides [11]. Any alteration in dopamine D1 and D2 receptors can cause modification in GABA neuronal migration to the cerebral cortex at the embryonic stage. Hence dopamine dis- 


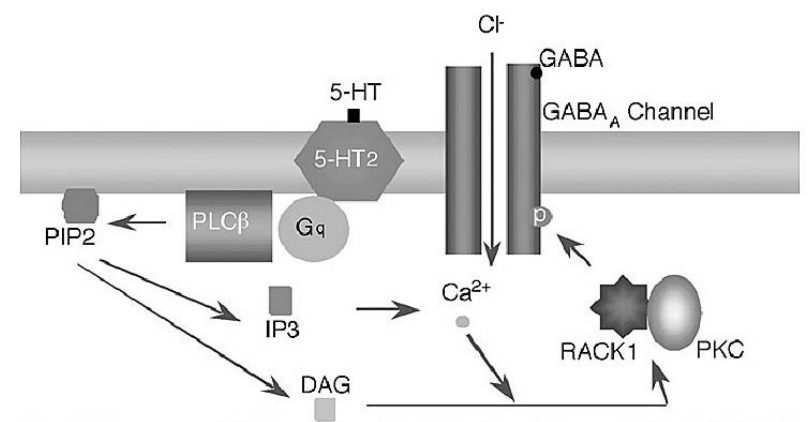

Figure 1. Diagram represent $\mathrm{GABA}_{\mathrm{A}}$ receptor regulation by signal transduction cascade through $5-\mathrm{HT}_{2}$ in prefrontal cortex. $5-\mathrm{HT}_{2} \mathrm{R}$ stimulates Phospholipase $\mathrm{C}$ results in the release of IP3 and DAG. Whereas PKC and RACK1 leads to phosphorylation of $\mathrm{GABA}_{\mathrm{A}} \mathrm{R}$ and hence reducing GABA currents.

parity during development can have an impact on GABA neurons expansion in multiple brain regions [12]. Prenatal intake of cocaine or DA receptor agonists can disrupt tangential migration of GABAergic neurons because GABAergic neurons in forebrain regions receive dopaminergic innervation when migrate to cortex during embryonic period. It has been reported that significant GABA dysfunction in multiple telencephalic regions is associated with multiple neuronal disorders including autism. Similarly, brain drive neurotropic factor (BDNF) attenuates inhibitory transmission and decrease the efficacy of inhibitory transmission by acute postsynaptic down regulation of $\mathrm{Cl}^{-}$transport. Similarly, cell adhesion molecules neurexins and neuroligins are trans-synaptic cell adhesion pair and are involved in synaptic functions. The interaction between neurexins and neuroligins are thought to trigger postsynaptic differentiation [13] and the balance between inhibitory GABA and excitatory glutamate inputs [14]. Other studies on mice carrying neuroligin3 (Nlgn3) gene mutation shows behavioral phenotypes related to ASD suggesting that the R451C mutation switches Nlgn3 synaptic specificity from glutamergic to GABAergic [15]. The branched chain amino acid (BCAA) is the combination of three essential amino acid leucine, isoleucine and valine and metabolism of BCAA is different from metabolic pathway of other amino acids. Mutation of Branched Chain alpha-Keto acid Dehydrogenase Kinase (BCKDK) gene which inactivates BCKD-kinase complex prevents the breakdown of BCAA. This BCKD-kinase mutation was reported in consanguineous families with autism, and total loss of kinase activity was present in homozygous participants [16]. Imbalanced excitation or inhibition of neurochemicals may be responsible for cytotoxicity in the developing brain and resultant behavioral deficits. GABA seems to be the most influential neurotransmitter during fetal development and any change in GABAergic migration and neurotransmission by monoamine neurotransmitters such as serotonin can alter GABAergic neuronal activity, migration and distribution. Suppressed GABAergic activity during critical period of development might result in the developmental disorders like autism and a peripheral marker such as platelet is essential for timely diagnosis of ASD and treatment effects.

GABAergic activities suggested to be crucial in pathophysiology of depressive behaviors and decreased GABA activity which would probably be a feature of a subset of mood disorder patients, possibly representing a genetic susceptibility to develop unipolar or bipolar disorder. However, neurotransmission of GABA appears to be involved in the mechanism of action of antidepressant and mood stabilizers. GABAergic pathways that appear to modulate monoaminergic and serotonergic systems, it is speculate that low basal GABA level can cause reduced levels of monoaminergic and serotonergic transmission and deficit in GABAergic neurotransmission in mood disorders would be complementary to the well-established alteration in monoaminergic and serotonergic systems which would suggest that an alteration in balance neurotransmission of these neurotransmitters (GABA, Serotonin) in depressive behaviors.

Depression can occur with autism however, clinical studies support that it is most common psychiatric illness seen in autism. In some cases depression in autism could occur by chance, or it could result from combination of genetic or environmental factors or both. The diagnostic criteria for people with depression in autism represent wide range of symptoms such as social withdrawal and appetite and sleep disturbance, and these are also core symptoms of depression. Depression can be reliably diagnosed in high functioning persons using same criteria as for the general population. Impairments in verbal and nonverbal skills can mask the symptoms of depression 
whereas, symptoms associated with autism such as obsession and self-injury may be increased during an episode of depression in autistic individuals [26]-[28].

\section{Authors and Affiliations}

Saima Khan from the Department of Biomedical Sciences, PAPRSB Institute of Health Sciences, University Brunei Darussalam, Brunei Darussalam and Kaneez Fatima Shad, Professor at the School of Medical and Molecular Biosciences, Faculty of Science, University of Technology Sydney (UTS), Broadway 2007, Australia. Whereas Hashmet Parveen Ghouse, PAPRSB Institute of Health Sciences, University Brunei Darussalam, Brunei Darussalam is co supervisor of Saima Khan

\section{Acknowledgements}

First author would like to acknowledge and thanks for the intellectual and physical contribution of supervisor Prof. Kaneez Fatima Shad as well as to PAPRSB Institute of Health Sciences, University Brunei Darussalam for giving the opportunity and support to carry on the research work. This commentary was based on the early work of Professor Fatima Shad elsewhere on neurotransmitters and platelets.

\section{References}

[1] Kaneez, F.S. and Saeed, S.A. (2009) Investigating GABA and Its Function in Platelets as Compared to Neurons. Platelets, 20, 328-333. http://dx.doi.org/10.1080/09537100903047752

[2] Shad, K.F. and Saeed, S.A. (2007) The Metabolism of Serotonin in Neuronal Cells in Culture and Platelets. Experimental Brain Research, 183, 411-416. http://dx.doi.org/10.1007/s00221-007-1133-7

[3] Rolf, L.H., Haarmann, F.Y., Grotemeyer, K.H. and Kehrer, H. (1993) Serotonin and Amino Acid Content in Platelets of Autistic Children. Acta Psychiatrica Scandinavica, 87, 312-316. http://dx.doi.org/10.1111/j.1600-0447.1993.tb03378.x

[4] Rojas, D.C., Teale, P.D., Maharajh, K., Kronberg, E., Youngpeter, K., Wilson, L.B. and Hepburn, S. (2011) Transient and Steady-State Auditory Gamma-Band Responses in First-Degree Relatives of People with Autism Spectrum Disorder. Molecular Autism, 2, 11. http://dx.doi.org/10.1186/2040-2392-2-11

[5] Sweatt, A.J., Garcia-Espinosa, M.A., Wallin, R. and Hutson, S.M. (2004) Branched-Chain Amino Acids and Neurotransmitter Metabolism: Expression of Cytosolic Branched-Chain Aminotransferase (BCATc) in the Cerebellum and Hippocampus. Journal of Comparative Neurology, 477, 360-370. http://dx.doi.org/10.1002/cne.20200

[6] Raymond, G.V., Bauman, M.L. and Kemper, T.L. (1995) Hippocampus in Autism: A Golgi Analysis. Actaneuropathologica, 91, 117-119. http://dx.doi.org/10.1007/s004010050401

[7] Cserep, C., Szabadits, E., Szőnyi, A., Watanabe, M., Freund, T.F. and Nyiri, G. (2012) NMDA Receptors in GABAergic Synapses during Postnatal Development. PloS One, 7, e37753. http://dx.doi.org/10.1371/journal.pone.0037753

[8] Hussman, J.P. (2001) Letters to the Editor: Suppressed GABAergic Inhibition as a Common Factor in Suspected Etiologies of Autism. Journal of autism and developmental disorders, 31, 247-248. http://dx.doi.org/10.1023/A:1010715619091

[9] Deutsch, S.I., Urbano, M.R., Neumann, S.A., Burket, J.A. and Katz, E. (2010) Cholinergic Abnormalities in Autism: Is There a Rationale for Selective Nicotinic Agonist Interventions? Clinical Neuropharmacology, 33, 114-120. http://dx.doi.org/10.1097/WNF.0b013e3181d6f7ad

[10] Morales, M. and Bloom, F.E. (1997) The 5-HT3 Receptor Is Present in Different Subpopulations of GABAergic Neurons in the Rat Telencephalon. The Journal of Neuroscience, 17, 3157-3167.

[11] Berger, B., Gasper, P. and Verney, C. (1991) Dopaminergic Innervation of the Cerebral Cortex: Unexpected Differences between Rodents and Primates. Trends Neuroscience, 14, 21-27. http://dx.doi.org/10.1016/0166-2236(91)90179-X

[12] Money, K.M. and Stanwood, G.D. (2013) Developmental Origins of Brain Disorders: Roles for Dopamine. Frontiers in Cellular Neuroscience, 7. http://dx.doi.org/10.3389/fncel.2013.00260

[13] Kang, Y., Zhang, X., Dobie, F., Wu, H. and Craig, A.M. (2008) Induction of GAB Aergic Postsynaptic Differentiation by $\alpha$-Neurexins. Journal of Biological Chemistry, 283, 2323-2334. http://dx.doi.org/10.1074/jbc.M703957200

[14] Graf, E.R., Zhang, X., Jin, S.X., Linhoff, M.W. and Craig, A.M. (2004) Neurexins Induce Differentiation of GABA and Glutamate Postsynaptic Specializations via Neuroligins. Cell, 119, 1013-1026. http://dx.doi.org/10.1016/j.cell.2004.11.035 
[15] Tabuchi, K., Blundell, J., Etherton, M.R., Hammer, R.E., Liu, X., Powell, C.M. and Südhof, T.C. (2007) A Neuroligin-3 Mutation Implicated in Autism Increases Inhibitory Synaptic Transmission in Mice. Science, 318, 71-76.

[16] García-Cazorla, A., Oyarzabal, A., Fort, J., Robles, C., Castejón, E., Ruiz-Sala, P. and Agulló, S.B. (2014) Two Novel Mutations in the BCKDK (Branched-Chain Keto-Acid Dehydrogenase Kinase) Gene Are Responsible for a Neurobehavioral Deficit in Two Pediatric Unrelated Patients. Human Mutation, 35, 470-477. http://dx.doi.org/10.1002/humu.22513

[17] Oleskevich, S. and Lacaille, J.C. (1992) Reduction of GABAB Inhibitory Postsynaptic Potentials by Serotonin via Preand Postsynaptic Mechanisms in CA3 Pyramidal Cells of Rat Hippocampus in Vitro. Synapse, 12, 173-188. http://dx.doi.org/10.1002/humu.22513

[18] Fraser, D.D. and MacVicar, B.A. (1991) Low-Threshold Transient Calcium Current in Rat Hippocampal Lacunosum-Moleculare Interneurons: Kinetics and Modulation by Neurotransmitters. The Journal of Neuroscience, 11, 2812 2820.

[19] McMahon, L.L. and Kauer, J.A. (1997) Hippocampal Interneurons Are Excited via Serotonin-Gated Ion Channels. Journal of Neurophysiology, 78, 2493-2502.

[20] Piguet, P. and Galvan, M. (1994) Transient and Long-Lasting Actions of 5-HT on Rat Dentate Gyrus Neurones in Vitro. The Journal of Physiology, 481, 629-639.

[21] Feng, J., Cai, X., Zhao, J. and Yan, Z. (2001) Serotonin Receptors Modulate GABA (A) Receptor Channels through Activation of Anchored Protein Kinase C in Prefrontal Cortical Neurons. Journal of Neuroscience, 21, 6502-6511.

[22] Munsch, T., Freichel, M., Flockerzi, V. and Pape, H.C. (2003) Contribution of Transient Receptor Potential Channels to the Control of GABA Release from Dendrites. Proceedings of the National Academy of Sciences, 100, 16065-16070. http://dx.doi.org/10.1073/pnas.2535311100

[23] Li, H., Lang, B., Kang, J.F. and Li, Y.Q. (2000) Serotonin Potentiates the Response of Neurons of the Superficial Laminae of the Rat Spinal Dorsal Horn to $\gamma$-Aminobutyric Acid. Brain Research Bulletin, 52, 559-565. http://dx.doi.org/10.1016/S0361-9230(00)00297-5

[24] Wang, D.S., Xu, T.L. and Li, J.S. (1998) 5-HT Potentiates GABA-and Glycine-Activated Chloride Currents on the Same Neurons in Rat Spinal Cord. Journal fur Hirnforschung, 39, 531-537.

[25] Xu, T.L., Pang, Z.P., Li, J.S. and Akaike, N. (1998) 5-HT Potentiation of the GABAA Response in the Rat Sacral Dorsal Commissural Neurones. British Journal of Pharmacology, 124, 779-787. http://dx.doi.org/10.1038/sj.bjp.0701896

[26] Ghaziuddin, M., Ghaziuddin, N. and Greden, J. (2002) Depression in Persons with Autism: Implications for Research and Clinical Care. Journal of Autism and Developmental Disorders, 32, 299-306. http://dx.doi.org/10.1023/A:1016330802348

[27] Stewart, M.E., Barnard, L., Pearson, J., Hasan, R. and O’Brien, G. (2006) Presentation of Depression in Autism and Asperger Syndrome: A Review. Autism, 10, 103-116. http://dx.doi.org/10.1177/1362361306062013

[28] Yan, Z. (2002) Regulation of GAB Aergic Inhibition by Serotonin Signaling in Prefrontal Cortex. Molecular Neurobiology, 26, 203-216. http://dx.doi.org/10.1385/MN:26:2-3:203 
Scientific Research Publishing (SCIRP) is one of the largest Open Access journal publishers. It is currently publishing more than 200 open access, online, peer-reviewed journals covering a wide range of academic disciplines. SCIRP serves the worldwide academic communities and contributes to the progress and application of science with its publication.

Other selected journals from SCIRP are listed as below. Submit your manuscript to us via either submit@scirp.org or Online Submission Portal.
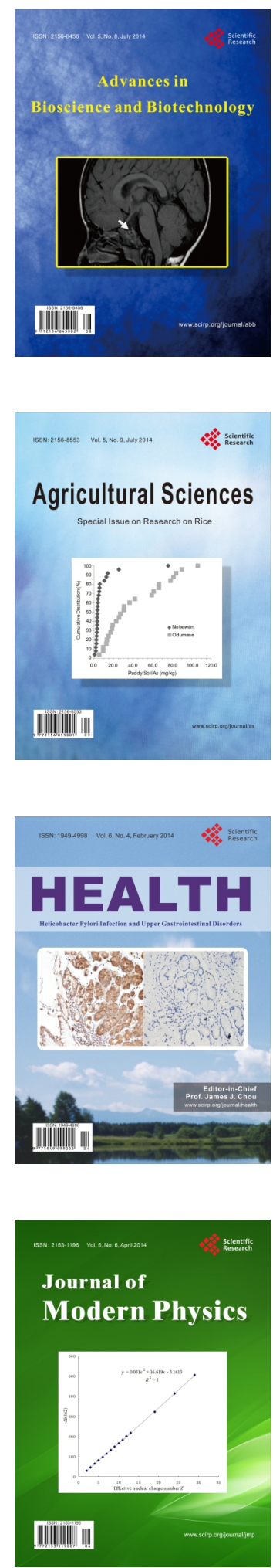
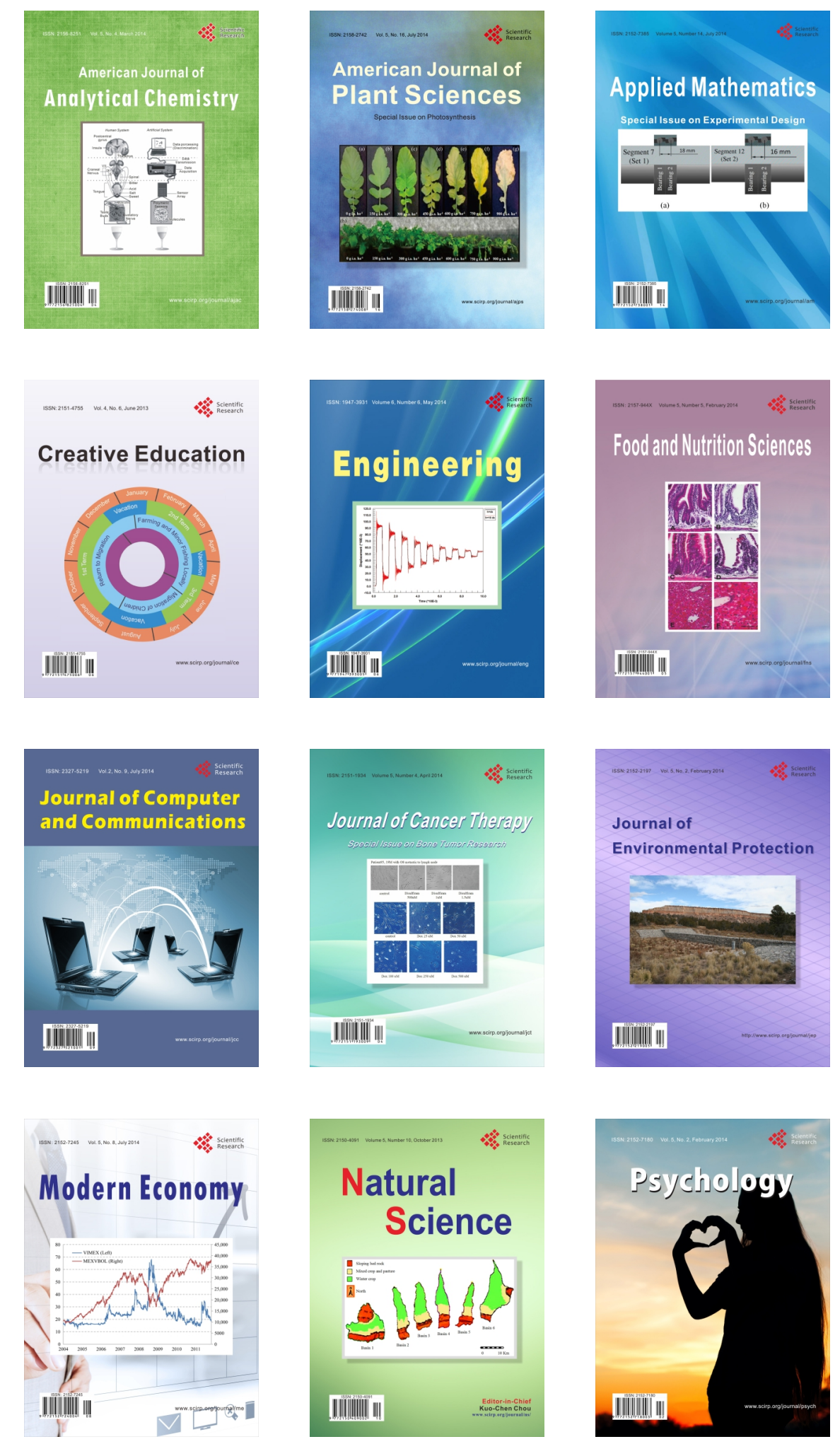